\title{
ESCHERICHIA COLI AS A POTENTIAL PATHOGEN IN BEEF BURGER
}

\author{
N.Y. Mostafa \\ ${ }^{1}$ Fac. Vet. Med. Kafrelsheikh University
}

\begin{abstract}
A total of 125 random samples of raw beef burger were collected from different localities in Alexandria Governorate 75 from super markets (25 each of three meat producing companies), 25 from butchers and 25 from small restaurants. All samples were examined for detection and enumeration of E. coli, results revealed that $45.7 \%$ of total examined samples were contaminated with $E$. coli. The highest incidence was among butcher's samples 64\%. Also results investigate that $31.6 \%$ of positive samples were over the allowable limit of $10^{2} /$ gram for E. coli.

- 10 selected burger samples with E. coli greater than $10^{3} / g$ were collected and cooked to investigate the effect of heating on E. coli count result investigate $98 \%$ reduction percent in $E$. coli count due to sufficient cooking.

- The sensitivity of isolated E. coli strains to different antibiotics was also discussed together with the public health significant of isolates E. coli strains.
\end{abstract}

\section{INTRODUCTION}

A beef burger is a sandwich that consists of patty of ground meat that is fried, steamed, grilled, or boiled, and is generally served with various toppings inside a sliced bun. (Edge and John, 2005). Beef burger is liable to contamination from different sources during its production, handling, packaging and storage. Insufficient cooking also plays an important role in surviving of some pathogens. Coliform 
organisms specially $E$. coli have probably received more attention than most other groups of pathogenic bacteria occurring in beef burger product owing to their importance as indicator species in routine analysis to ascertain the quality of this product and other meat products. Various diseases in animals and human are associated with different types of $E$. coli (Brien et al., 1982 and Strockbine et al., 1986) various strains of $E$. coli causes haemorrhagic colitis with mortality rate of 36\% (Riley, 1987), and Haemolytic Uremic Syndrome (HUS) which causes long term kidney damages and death several years after (Morrison et al., 1986). E. coli $\mathrm{O} 157$ poisoning is called "Barbecue season syndrome" which often happens when people cook beef burgers on barbecue improperly. Its medical name is Heamorrhagic colitis (Kenneth et al., 2002). E. coli poisoning diseases costs their victims allover the world millions of dollars, (Pritzker and Ruochonem, 2006). Thus monitoring of beef burger for $E$. coli is needed to throw light on the hygienic quality of the beef-burger sold at the market.

\section{MATERIAL AND METHODS}

A total of (125) random samples of frozen beef burger sectioned into 5 groups (25 each) according to its source. Groups A, B are representing 2 of the biggest meat producing company. C (small meat producing company. D (butcher shops) and E (small restaurants). All samples were transferred to the laboratory with a minimum time of delay in an ice-box and examined microbiologically.

The collected samples were prepared for examination quantitatively for incidence of E. coli according to (APHA, 1992), to be counted by the most probable number technique (MPN/g) according to (Banwart, 1979). This technique was applied on Lauryl sulphate tryptose broth as selective 
media (ICMSF, 1978), followed by confirmation on Brilliant green lactose bile broth. Positive culture were confirmed on selective agar media which was MaConkey agar. 5 typical pink pigmented colonies were picked from each sample and indole test was applied according to (Kovacs, 1978), methyl red test and Vogus proskeur test (Macfaddin, 1976), Citrate Utilization (Simmon, 1926). (10) selected beef burger samples with E. coli m.o. count of greater than $10^{3} / \mathrm{g}$ were cooked to compare the number of $E$. coli in beef burger samples before and after cooking. Typical strains of E. coli were tested for its anti-biotic sensitivity by means of antibiotic discs which are Commercially available. As cephalosporoines, Gentamycin, Tetracycline, Streptomycin, Ampicillin, Novobiocin. Isolates proved biochemically to be E. coli were subjected to serological identification in the Laboratory of Ministery of Health, Cairo, Egypt.

\section{RESULTS}

Table (1): Statistical analytical results of total E. coli count in examined beef burger samples.

\begin{tabular}{|c|c|c|c|c|c|}
\hline \multirow{2}{*}{$\begin{array}{c}\text { No. of examined } \\
\text { samples }\end{array}$} & \multicolumn{2}{|c|}{ Positive samples } & \multirow{2}{*}{ Min. } & \multirow{2}{*}{ Max. } & \multirow{2}{*}{ Mean \pm S.E. } \\
\hline & $\mathrm{No}$ & $\%$ & & & \\
\hline 125 & $\overline{57}$ & 445.7 & $0.7 \times 10$ & $2.4 \times 10^{3}$ & $3.8 \times 10^{2}+6.4 \times 10$ \\
\hline
\end{tabular}

Table (2): Statistical analytical results of $E$. coli count in examined beef burger samples groups.

\begin{tabular}{|c|c|c|c|c|c|c|}
\hline \multirow[b]{2}{*}{ Group } & \multirow{2}{*}{$\begin{array}{c}\text { No. of } \\
\text { examined } \\
\text { samples }\end{array}$} & \multicolumn{2}{|c|}{ Positive samples } & \multirow{2}{*}{ Min. } & \multirow{2}{*}{ Max. } & \multirow[b]{2}{*}{ Mean \pm S.E. } \\
\hline & & No & $\%$ & & & \\
\hline A & 25 & 13 & 52 & $0.7 \times 10$ & $2.4 \times 10^{3}$ & $4.1 \times 10 \pm 1.7 \times 10$ \\
\hline B & 25 & 9 & 36 & $0.7 \times 10$ & $1.5 \times 10^{3}$ & $3.6 \times 10 \pm 1.4 \times 10$ \\
\hline $\mathrm{C}$ & 25 & 12 & 48 & $1.5 \times 10$ & $1.1 \times 10^{3}$ & $2.4 \times 10^{2} \pm 1.2 \times 10^{2}$ \\
\hline $\mathrm{D}$ & 25 & 16 & 64 & $7.5 \times 10$ & $2.4 \times 10^{3}$ & $6.5 \times 10^{2} \pm 1.6 \times 10^{2}$ \\
\hline $\mathrm{E}$ & 25 & 7 & 28 & $3.5 \times 10$ & $1.1 \times 10^{3}$ & $2.3 \times 10^{2} \pm 1.4 \times 10^{2}$ \\
\hline
\end{tabular}


Table (3): Statistical analytical results of E. coli count in raw, and cooked beef burger samples.

\begin{tabular}{|c|c|c|c|c|c|c|c|}
\hline \multirow{2}{*}{$\begin{array}{l}\text { Type of } \\
\text { product }\end{array}$} & \multirow{2}{*}{$\begin{array}{c}\text { No. of } \\
\text { samples }\end{array}$} & \multicolumn{2}{|c|}{ Positive samples } & \multirow{2}{*}{ Min. } & \multirow{2}{*}{ Max. } & \multirow{2}{*}{$\begin{array}{l}\text { Mean } \pm \\
\text { S.E. }\end{array}$} & \multirow{2}{*}{$\begin{array}{l}\% \text { of reduction in } \\
\text { the mean value }\end{array}$} \\
\hline & & No & $\%$ & & & & \\
\hline Raw & 10 & 10 & 100 & $1.0 \times 10^{3}$ & $2.4 \times 10^{3}$ & $1.2 \times 10^{3} \pm 1.3 \times 10^{2}$ & \multirow{2}{*}{$\% 98$} \\
\hline Cooked & 10 & 4 & 40 & $0.7 \times 10$ & $3.5 \times 10$ & $1.9 \times 10 \pm 0.6 \times 10$ & \\
\hline
\end{tabular}

Table (4): Antibiotic sensitivity patterns for typical E. coli isolates.

\begin{tabular}{|c|c|c|c|c|c|}
\hline Cephalosporine & Gentamycin & Sterptomycin & Tetracycline & Ampicillin & Novobiocin \\
\hline+++ & ++ & ++ & ++ & -- & - \\
\hline
\end{tabular}

Table (5): Serological identification of the typical polyvalent $E$. coli isolates.

\begin{tabular}{|c|c|c|c|c|}
\hline \multicolumn{3}{|c|}{ The isolates } & \multirow{2}{*}{ The result of the polyvalent $O$} & \multirow{2}{*}{ Classification of the species } \\
\hline & No & $\%$ & & \\
\hline & 5 & 9.6 & E. coli polyvalent $\mathrm{O} 4$ & $\begin{array}{l}\text { - Enteropathogenic class II } \\
\text { - Enteroinvassive }\end{array}$ \\
\hline & 52 & 90.4 & E. coli polyvalent $\mathrm{O} 3$ & - Enteropathogenic class I \\
\hline Total & 57 & $100 \%$ & & \\
\hline
\end{tabular}

\section{DISCUSSION}

From the results achieved in Table (1) it is evident that $E$. coli was isolated from $57(45.7 \%)$ of the total examined 125 raw beef burger samples, that indicates general high percentage of contamination among the produced beef burger samples at the market. This percentage is much more than obtained by Iman (1990), Yassien et al. (1998), Marcela and Valeria (2003), Stampi et al. (2004) and Hussien (2007). The mean value $380 \mathrm{cfu} / \mathrm{g}$ is much more than permissible limit of $E$. coli in beef burger product according to (Egyptian Organization for Standardization and Quality Control, 2005) and (Canadian Food Inspection Agency, 2005), and much more than the mean value administrated by (Geoff et al., 2008) which may unfortunately due to lower level of hygiene in producing our meet local product. 
Results obtained from Table (2) reveal that the highest incidence of E. coli was among butcher shops (64\%), that represents quiet high load of contamination among the hand made beef burger, which was much more than the results obtained by (Cagney et al., 2004), but it agrees with that obtained by (Stampi et al., 2004).

Results obtained by Table (3) reveal that that cooking temperature has caused $98 \%$ reduction of the $E$. coli total number in the examined samples. This result is nearly similar to (Bryant, 2001) and (ETATS, 1997).

Table (4) showed the high susceptibility of E. coli to Cephalosoporines followed by moderate susceptibility to Gentamycin, Streptomycin and Tetracycline and little susceptibility to Ampicillin and Novobiocin such results nearly agree with that obtained by Fontana and Bada (2006) and Aslam et al. (2006).

Table (5) results of the serological identification of positive E. coli isolates revealed that $9.6 \%$ of the isolates belonged to enteropathogenic E. coli class II, and enteroinvassive E. coli and $90.4 \%$ enteropathogenic $E$. coli class I such results show quite different from results obtained by (Giono and Angles, 1994) and (Adwan and Adwan, 2004) which may attributed to weather strains were more predominant in each locality.

The results of this work indicated that there is poor quality of the general beef burger processing and there is a gap in awareness of quality control measures all over the beef burger industry process with a concept that hand made products are the worst polluted ones, hence that normal cooking process temperature is a very efficient to almost elimination of E. coli in beef burger. 


\section{REFERENCES}

- Adwan, G.M. and Adwan, K.M. (2004). Isolation of Shiga toxigenic E. coli from raw beef in Palestine. Int. J. Food Microbiol., Dec. 1; 97(1): 81-4.

- American Public Health Association (1992). Compendium of methods for the microbiological examination of foods. $3^{\text {rd }}$ ED. Wessington, DC, USA.

- Aslam, M. (2006). Antimicrobial Resistance and genetic profiling of E. coli from a commercial beef packing plant. J. Food Prot. Jul, 69(7): 1508-13.

- Banwart, G.J. (1979). Basic Food Microbiology Text Book Chapter II (Estimating the number of microorganisms), page, 37. Library of Congress Cataloging in Publication Data.

- Brien, A.D.; LaVeck, C.D.; Thompson, M.R. and Formal, S.B. (1982). Production of Shigella dysenteriae type I- like cytotoxin by $E$. coli. J. Inf. Dis., 146: 763-769.

- Bryant, J.; Gill, C.O. and Badoni, M. (2001). Effects of hot water pasteurizing treatments on the microbiological condition of manufacturing beef used for hamburger patty manufacture. Int. J. Food Microbiol., Feb. 15; 63(3): 243-56 links.

- Cagney, C.; Crowley, H.; Duffy, G.J.; Sheridan, J. and Brine, S. (2004). Prevalence and numbers of Escherchia coli O157: H7 in minced beef and beef burgers from butcher shops and supermarkets in the Republic of Ireland. Food Microbiology, Volume 21, Issue 2, April 2004, Pages 203-212.

- Canadian Food Inspection Agency (2005). "E. coli O157: H7 Myths vs Reality". http://www.inspection.gc.ca/English/ corpaffr/ food facts/shtml mythe. 
- Edge, D. and John, T. (2005). Hamburgers \& Fries: an American Story. G.P. Putnam's Sons. ISBNO-399-15274-1. History and Origins of the Hamburger.

- Egyptian Organization for Standardization and Quality Control “E.O.S.Q.C”(2005).Egyptian standard for requirements of hamburger, No. 1688.

- ETATS (1997). International Association of Milk, Food and Environmental Sanitarians, J. of Food Protection, Vol. 60: 1163-1166 (16ref.).

- Fontana, A. and Bada, A.B.R. (2006). Antibiotic resistance of E. coli strains isolates from raw chicken meat in Senegal. J. Dakar Med.; 51(1): 57-62.

- Geoff, H.; Andrew, P.; Michelle, L.; Andreas, K.; Geoff, R. and John, S. (2008). Microbial profiles of carcasses and minced meat from kangaroos processed in South Australia. Int. J. Food Microb. March 123(1-2): 88-92.

- Gino, C.S and Angeles, M.G. (1994). Identification of enterotoxins and cytotoxins of $E$. coli by Vero cell culture and solid phase hybridization (colony blot). J. Rev. Latin Microbiol, Oct-Dec.; 36(4): 231-41. Links.

- Hussein, H.S. (2007). Prevalence and pathogenicity of Shiga toxinproducing Escherichia coli in beef cattle and their products. J. Anim. Sci., 2007. 85: E63-E72. Doi: 10.2527/has 2006-421.

- Internatioanl Commission of Microbiological Specification for Foods "ICMSF" (1978). Microorganisms in food, their significance and methods of enumeration, $2^{\text {nd }}$ Ed. Univ. of Toronto and Buffalo, Canada.

- Iman, I. (1990). Incidence of E. coli in meat products. Thesis, M.V.Sc., Meat Hygiene, Fac. Vet. Med., Cairo University. 
- Kenneth, T. (2002). University of Wisconsin-Madison, Department of Bacteriology. Bacteriology 330 Home Page.

- Kovacs, N. (1978). A simplified method for detection of indol formation by bacteria. Z. Immunitats Fosh., 56, 311.

- Macfaddin, J.F. (1976). Biochemical tests for identification of medical bacteria. Warery Press, Inc. Baltimore, Md. 21202 USA.

- Marcela, A. and Valeria, P. (2003). Detection of Shiga toxinproducing Escherichia coli in food. Expert Review of Molecular Diagnostics, 3: 1, 105.

- Morrison, D.M.; Tyrell, D.I.J. and Jewell, L.D. (1986). Colonic biopsy in verotoxin-induced hemorrhagic colitis and thrombotic thrombocytopenic purpura (TTP). Am. J. Clin. Path., 86, 108, 112.

- Pritzker, L. and Ruohonem, S. (2006). Food poisoning law Blog published By Pritzker/Ruohonen Org. E. coli Food Safety, Recalls E. coli in hamburger can make you children sick.

- Riley, L.W. (1987). The epidemiological, clinical and microbiologic features of hemorrhagic colitis, Ann, Rev. Mic,., 41, 383-408.

- Simmon, J.S. (1926). A culture medium for differentiating organisms of the typhoid aerogenes groups and the isolation of certain fungi. J. Infect. Dis., 39, 209.

- Stampi, S.; Capsioali, A.; De Luca, G.; Quaglio, P.; Sacchetti, R. and Zanetti, F. (2004). Detection of E. coli $\mathrm{O} 157$ in bovine meat products in northern Italy Int. J. of Food Microbiology. 90: 257-262.

- Strockbine, N.A.; Marques, I. and Newland, R.M. et al. (1986). Two toxin-converting phages form $E$. coli O157: H7 strain 933 encode antigenically distinct toxins with similar biological activities. Inf. Imm., 53, 135-140.

- Yassien,N.;Ibrahim,A. and Elmossalami, M.E. (1998). Fluorescence assay for rapid detection of $E$. coli in meat products. Fleischwirts Chaft, 78(5): 505-506. 
الاشريكية القولونية كمرضة احتمالية فى البرجر البقرى

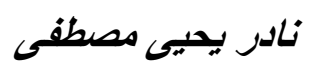

\section{قسم مراقبة الاغذية ـ كلية الطب البيطرى · جامعة كفر الثيخ}

تم جمع 125 عينة من الهامبورجر المجد من خمسة مصادر مختلفة من اسواق مدينة الاسكندرية ، كل مصدر يحتوى على 25 عينة وهم كالاتى: المجموعة الاول والثانية من شركات مصنعات اللحوم الكبيرة والمعروفة ـ أما المجموعة الثالثة فهى لاحدى شركات مصنعات اللحوم الجديدة بالنسبة للسوق حاليا. المجموعة الرابعة تعبر عن محلات الجزارة والتى تقولم بتصنيع الهامبورجر بطريقة يدوية ، أما بالنسبة للمجموعة الخامسة والاخيرة فهى تعبر عن عينات نيئة من المطاعم الصغيرة

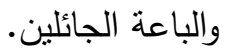

نظرا لاهمية تأثير الحرارة المستخدمة فى الطهى فى القضاء على ميكروب الاشريكية القولونية بنسبة كبيرة لهذا نم اختيار بعض العينات وعددها عشرة عينات وجد انها تحتوى على عدد اكبر من (310) ميكروب/جرام من الهامبورجر لطهيها فى درجة الحرارة المنزلية ثم إجراء اختبار العد ثانية لدراسة مدى تأثثر الطهى الجيد على الحد من نواجد هذه الميكروبات. وقد أسفرت الدر اسة عن النتائج الآتية:

وجد ان نسبة نواجد ميكروب الاشريكية القولونية وصلت الى 45\% فى العينات المختبرة وهى نسبة عالية لتواجد هذا الميكروب فى منتج الهامبورجر ، كما وجد ان اعلى معدل لتواجده بين الخمس مجموعات كان فى مجموعة الجزارين 64\% . منتسط العد الكلى لميكروب الايشيرييشيا كولاى كان 380 Kafrelsheikh Vet. Med. J. Vol. 6 No. 2 (2008) 
ميكروب/جرام أما بالنسبة لنتيجة العد بعد الطهى فقد وحد ان منوسط نسبة الاختلاف فى العد قبل الطهى وبعده فى العشر عينات المختبرة كان 98\% وهى تعد نسبة جيدة كمؤشر لمدى تأثير هذه الحرارة فى القضاء على الميكروب.

أسفرت نتائج قياس مدى حساسية ميكروب الاتشريكية القولونية للمضادات الحيوية ان مضاد

السفالوسبورين هو الاكثر نأثيرا يلية الجنتاميسين والاستربتومايسين والتتراسيكلين ويأتى النوفوبايوسين كأقل المضادات الحيوية تأثنيرا على الميكروب.

تم تصنيف معزولات ميكروب الايشريشيا كولاى الناتجة عن الدراسة ونم ارسالها الى المعمل المركزى الخاص بوزارة الصحة بالقاهرة فظهرت فصيلة ال: انتيروباثوجينيك كلاس 1 ، انتيروباثوجينيك كلاس 2 ، الانتيروانفسيف وهى فصائل نسبب اعراض الاسهال واضطرابات الجهاز الهضى وارتفاع درجات الحرارة بسب ما تفرزه من سموم.

وقد نوقثت أهية الميكروب المعزول من الناحية الصحية كما نوقشت النتائج التى نم الحصول عليها وتم مقارنتها بنتائج الباحثين السابقين. 